\title{
Evaluasi Penerapan Program Penghematan Air Bersih di Gedung Perkantoran (Studi Kasus Penghematan Air Bersih di Gedung Perkantoran PT TEPI)
}

\author{
Siska Ayu Kartika ${ }^{1}$ \\ ${ }^{1}$ Program Studi Teknik Mesin Universitas Balikpapan \\ E-mail: siska.ayukartika@uniba-bpn.ac.id
}

\begin{abstract}
Demand and water use every year are increasing, inline with the rapid growth of population, industrial and office buildings. PT TEPI as one of company in Balikpapan, is called to take parts in the effort to implement water saving efforts for a better future in the world and in line with the implementation of Environmental Management System ISO 14001 in that company. The purpose of writing this paper is to identify the efforts which must be done in implementing water savings efforts in office buildings and to evaluate water saving program which have been done. The methodology of this research is collecting some supporting data, survey and site observation, evaluating water use and calculate the reducing of water saving which could be done before and after improvements. Several efforts to save water which have been done such as commitment from top management to fully support the movement of water saving program, establish energy and water saving committee, socialization to improve employee awareness, water leak detection, repair the broken valve/water meter, replace manual water tap with autostop water tap, using dual flush toilet, and sprinkler for watering garden. Through this movement TEPI has significantly decreased water use $34,18 \%$, from $2009-2017$, and average of water consumption is 312,44 L/person/day.
\end{abstract}

Keywords: Office buildings, Water consumption, Water saving efforts

\begin{abstract}
Abstrak
Kebutuhan dan pemakaian air bersih terus meningkat setiap tahunnya, seiring dengan pertumbuhan penduduk, jumlah industri dan gedung-gedung perkantoran. PT TEPI sebagai salah satu perusahaan di Balikpapan, berpacu untuk turut serta melakukan upaya penghematan air demi masa depan yang lebih baik, sejalan dengan penerapan Sistem Manajemen Lingkungan ISO 14001 diperusahaan tersebut. Tujuan dari penulisan paper ini adalah untuk melakukan identifikasi upaya-upaya dalam melaksanakan kegiatan penghematan air di gedung perkantoran dan mengevaluasi penerapan program penghematan penggunaan air bersih yang telah dilakukan. Metodologi penelitian ini dilakukan dengan mengumpulkan data sekunder, melakukan survei dan obervasi lapangan, mengevaluasi penggunaan air bersih dengan menghitung berapa penghematan yang dapat dilakukan sebelum dan sesudah dilakukan beberapa perbaikan. Program penghematan air yang telah dilakukan diantaranya adalah komitmen dari manajemen puncak untuk mendukung secara penuh pada gerakan penghematan air, pembentukan tim komite hemat energi dan air, melakukan sosialisasi peningkatan kesadaran karyawan, deteksi kebocoran air, memperbaiki kran bocor dan meter air yang rusak, mengganti kran manual menjadi kran autostop, pemakaian dual flush toilet, dan sprinkler untuk menyiram tanaman. Melalui gerakan ini, PT TEPI telah melakukan penurunan pemakaian air sebesar $34,18 \%$ terhitung mulai dari tahun 2009- 2017, dan rata-rata pemakaian air perkapita adalah sebesar 312,44 L/orang/hari.
\end{abstract}

Kata kunci: Gedung perkantoran, Pemakaian air, Upaya penghematan air

\section{PENDAHULUAN}

Air bersih merupakan salah satu kebutuhan dasar manusia yang berdampak langsung kepada kesejahteraan fisik, sosial dan ekonomi masyarakat. Sungai yang menjadi sumber air bersih sudah tercemar mulai dari air limbah domestik hingga limbah beracun dari industri. Pemakaian air tanah yang terus menerus dengan 
jumlah yang besar mengakibatkan menurunnya cadangan air tanah [1].

Selain itu kualitas air tanah semakin menurun akibat instrusi air laut dan pencemaran buangan air limbah rumah tangga. Salah satu upaya untuk menghindari kelangkaan air bersih adalah melakukan penghematan penggunaan air bersih dan melakukan upaya-upaya konservasi sumber daya air. Sebagai upaya untuk penghematan air, Pemerintah telah menerbitkan beberapa peraturan terkait antara lain:

(1) Peraturan Pemerintah Nomor 42 Tahun 2008 tentang Pengelolaan Sumber Daya Air [2]

(2) Instruksi Presiden Republik Indonesia Nomor 13 Tahun 2011 Tentang Penghematan Energi dan Air [3]

(3) Peraturan Menteri Energi dan Sumber Daya Mineral Republik Indonesia Nomor 15 Tahun 2012 Tentang Penghematan Penggunaan Air Tanah [4].

Mengacu pada peraturan tersebut diatas, setiap gedung perkantoran khususnya milik pemerintah mempunyai kewajiban untuk melakukan penghematan air. PT TEPI sebagai salah satu perusahaan di Balikpapan, yang juga menerapkan Sistem Manajemen Lingkungan ISO 14001, mendukung penuh kegiatan penghematan air ini, dan berupaya melakukan kajian terhadap semua kegiatan pemakaian air melalui upaya penghematan pemakaian air bersih, melakukan konservasi air dan menjaga ketersediaan sumberdaya air.

PT TEPI mempunyai beberapa gedung perkantoran terpisah, dengan luas lahan perkantoran sekitar 2,5 ha dan luas lantai bangunan kurang lebih dari $30.000 \mathrm{~m}^{2}$. Sumber utama air bersih berasal dari air sumur bawah tanah yamg diolah sendiri diunit pengolahan air bersih PT TEPI, dan ditampung dalam ground tank dengan kapasitas volume $240 \mathrm{~m}^{3}$ yang didistribusikan ke beberapa tangki penyimpanan air.

Tujuan dari penulisan paper ini adalah untuk melakukan identifikasi upaya-upaya penghematan air bersih di gedung TEPI dan mengevaluasi seberapa besar penghematan penggunaan air bersih yang dapat dilakukan sebelum dan sesudah program penghematan penggunaan air bersih dilakukan.

\section{METODOLOGI}

Obyek penelitian ini adalah gedung perkantoran PT TEPI di Balikpapan dan meliputi kegiatan:

(1) Pengumpulan data primer dan sekunder.

(2) Survei \& observasi lapangan di gedung perkantoran.

(3) Survei unit pengolahan air bersih, kondisi sistem distribusi air ke Gedung perkantoran, peralatan dan data pendukung.

Metodologi yang digunakan dalam kegiatan ini adalah :

(1) Studi Pustaka,

(2) Interview dan observasi,

(3) Analisis upaya-upaya efisiensi hemat air,

(4) Perhitungan penghematan air sebelum dan setelah dilakukan upaya-upaya.

\section{HASIL DAN PEMBAHASAN}

Beberapa upaya yang telah dilakukan PT. TEPI untuk dapat menghemat air antara lain adalah:

a. Komitmen Top Manajemen

Top manajemen perkantoran harus mempuyai komitmen yang mendukung secara penuh gerakan penghematan energi dan air. Tanpa komitmen tersebut implementasi gerakan hemat energi \& air tidak akan sukses. Pimpinan Puncak PT. TEPI pada tanggal 12 Maret 2009 telah menandatangani komitmen untuk mendukung kebijakan program pemerintah di bidang penghematan energi dan air melalui upaya:

(1) Menjadikan kantor PT. TEPI sebagai kantor yang bersih, hemat energi dan air;

(2) Mengembangkan budaya PT. TEPI ke arah budaya bersih, hemat energi dan air;

b. Pembentukan Tim Komite

Sejalan dengan komitemen pimpinan puncak untuk menyelamatkan bumi demi masa depan generasi penerus, serta upaya untuk melakukan penghematan penggunaan sumber daya alam, maka PT. TEPI berinisiatif untuk membentuk Komite Hemat Energi \& Air (gambar 1) yang bertugas untuk melakukan kegiatan penghematan energi dan air. Tugas tim adalah:

(1) Melakukan koordinasi kegiatan-kegiatan penghematan energi dan air;

(2) Memantau segi penghematan energi dan air di lingkungan Pt. TEPI;

(3) Melakukan kajian dan evaluasi penghematan energi dan air. 


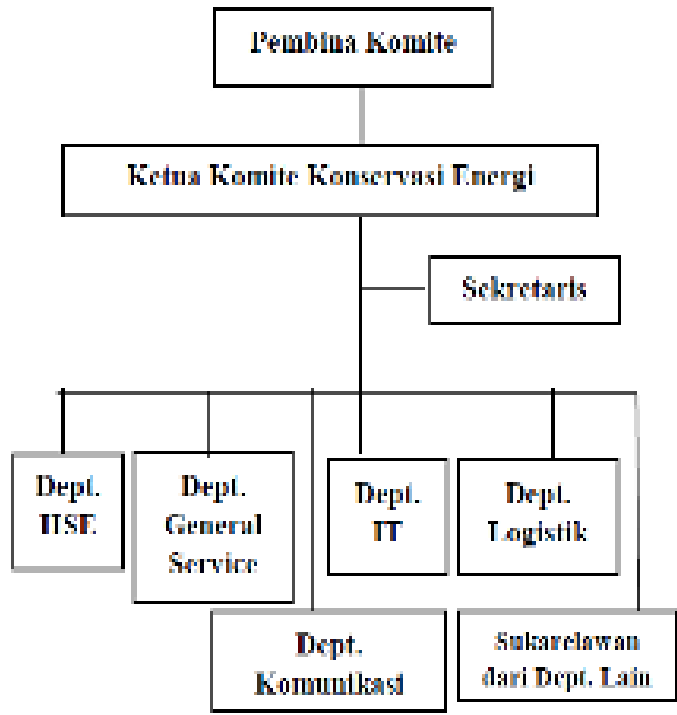

Gambar 1. Struktur Komite

Konservasi Energi dan Air di TEPI

c. Studi Pendahuluan Pemakaian Air

Studi Pendahuluan ini dimaksudkan untuk melakukan evaluasi terhadap semua kegiatan penggunaan air ditinjau dari sisi penghematan, pengawasan dan cara menggunakan sumber daya secara efisien. Inventarisasi data akan dilakukan dengan mengumpulkan data kondisi, pemakaian air untuk kebutuhan gedung dan pegawai serta kondisi keran, kamar mandi, toilet dan lainnya. Berdasarkan data-data yang terkumpul akan dilakukan pengolahan, analisa, dan evaluasi serta rekomendasi pemakaian air di gedung TEPI. bahwa :

Hasil studi pendahuluan didapatkan data

(1) Sudah ada pencatatan pemakaian air per gedung setiap bulannya, mulai tahun 2007. Seperti terlihat pada gambar 2 .

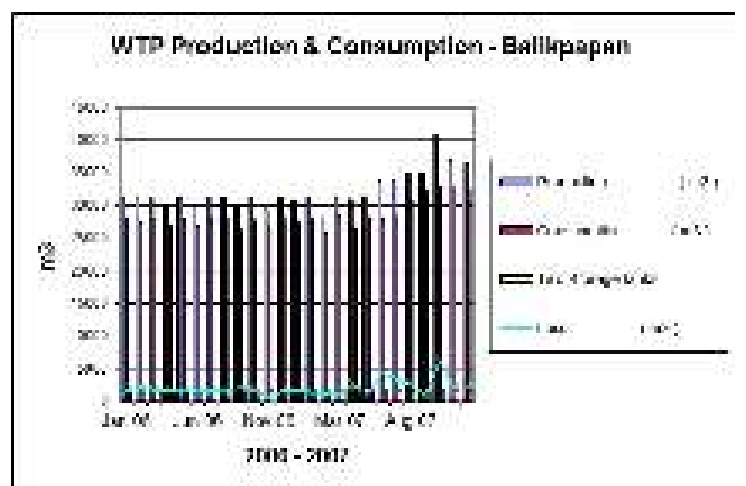

Gambar 2. Laporan Produksi dan Pemakaian Air Bersih tahun 2006 - 2007
(2) Meter air yang terpasang tidak terkalibrasi secara periodik.

(3) Belum adanya evaluasi pemakaian air setiap bulannya, terutama untuk mengetahui ada/tidaknya kebocoran

(4) Ketidakseimbangan antara air bersih yang diproduksi dari Unit Pengolahan Air Bersih dengan Catatan Pemakaian setiap bulannya.

(5) Tidak adanya evaluasi dari ketidakseimbangan data produksi dan pemakaian, apakah disebabkan karena kebocoran di unit produksi, distribusi, instalasi pemadam kebakaran, servis ke maryarakat sekitar, dll.

(6) Adanya kebocoran dibeberapa titik unit hydrant, kran air, toilet, urinoar dan kran wastafel dan dapur

(7) Adanya kebocoran di unit pipa distribusi air bersih

(8) Belum dilakukannya kegiatan untuk melakukan deteksi kebocoran di unit distribusi air bersih secara periodik

(9) Belum dilakukannya program pemeliharaan untuk unit pengolahan air bersih, misalnya pemeliharaan cooling tower yang mulai berkarat, modifikasi dynasand filter, inspeksi periodic untuk mengevaluasi performance pipa, penggantian pipa yng berkarat, level sensor tangka penyimpanan air, dll.

Hasil terhadap pemakaian air diperoleh beberapa rekomendasi antara lain :

(1) Pemasangan meter air di beberapa titik yang berpotensi terjadi kebocoran.

(2) Perbaikan dan penggantian meter air yang rusak.

(3) Penggantian keran air manual menjadi keran tekan/autostop atau keran sensor.

(4) Perlu standar waktu bukaan keran autostop sehingga lebih menghemat.

(5) Perlu pemeriksaan secara berkala kondisi keran, urinoir, shower, toilet sehingga apabila ada kerusakan, kebocoran cepat diperbaiki.

d. Sosialisasi

Sosialisasi penghematan air yang merupakan bagian dari program yang telah dilaksanakan PT TEPI kepada seluruh pegawai di unit yang ada dilingkungan PT TEPI termasuk pegawai outsoursing (satpam, cleaning service, office boy) untuk menjelaskan mengenai Manajemen Pengelolaan dan Penghematan Air di Perkantoran. Disamping sosialisasi, 
untuk meningkatkan kesadaran terhadap penghematan air juga dilakukan kampanye melalui pemasangan stiker, poster dan banner serta spanduk di seluruh kantor TEPI, seperti terlihat pada gambar 3 dan 4 berikut ini.

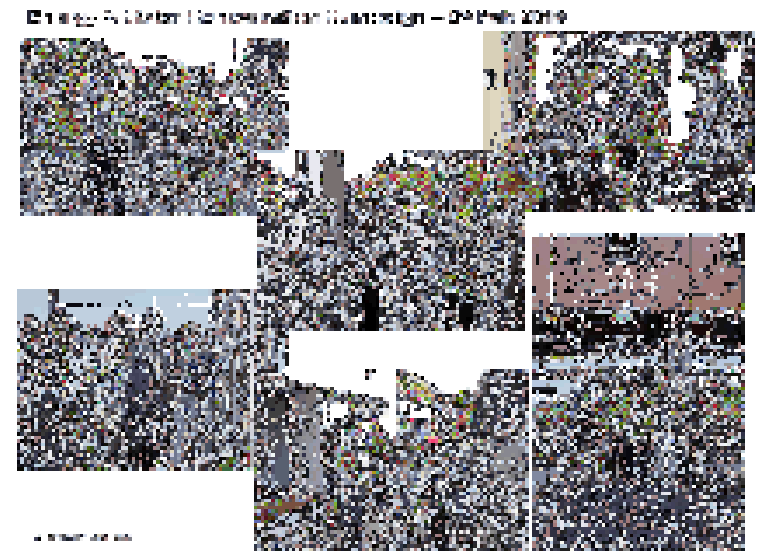

Gambar 3. Kegiatan sosialisasi ke karyawan dengan membagikan leaflet mengenai program penghematan penggunan air bersih
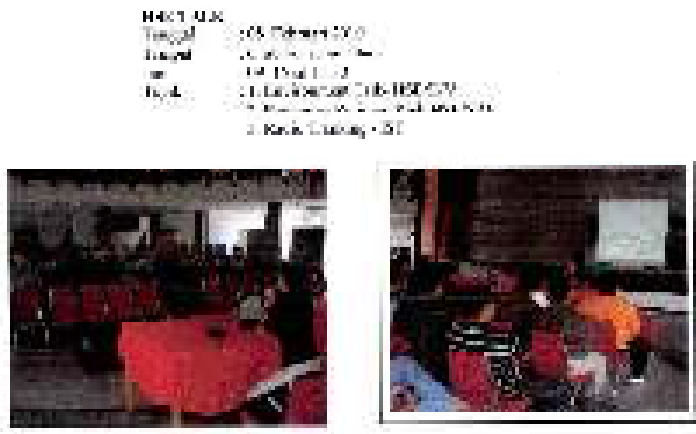

Gambar 4. Kegiatan sosialisasi ke karyawan dengan mengadakan workshop mengenai program penghematan penggunan air bersih

e. Melakukan kegiatan deteksi kebocoran

Prosedur deteksi kebocoran yang dilakukan adalah dengan mencatat pemakaian air dari jam 23.00 hingga 03.00 dini hari, dengan menutup semua kran pipa distribusi ke warga sekitar. Sedangkan semua kran pipa distribusi dari unit pengolahan air bersih ke gedung perkantoran dibuka. Adapun jalur pipa dan sebagainya dapat dilihat pada gambar 5 dan 6 .

Selain program deteksi kebocoran ini mulai dijadwalkan untuk dilaksanakan secara berkala, juga bekerja sama dengan petugas cleaning service dan taman, untuk segera memberitahukan jika mengetahui adanya kebocoran pada kran atau saluran pipa distribusi lainnya.

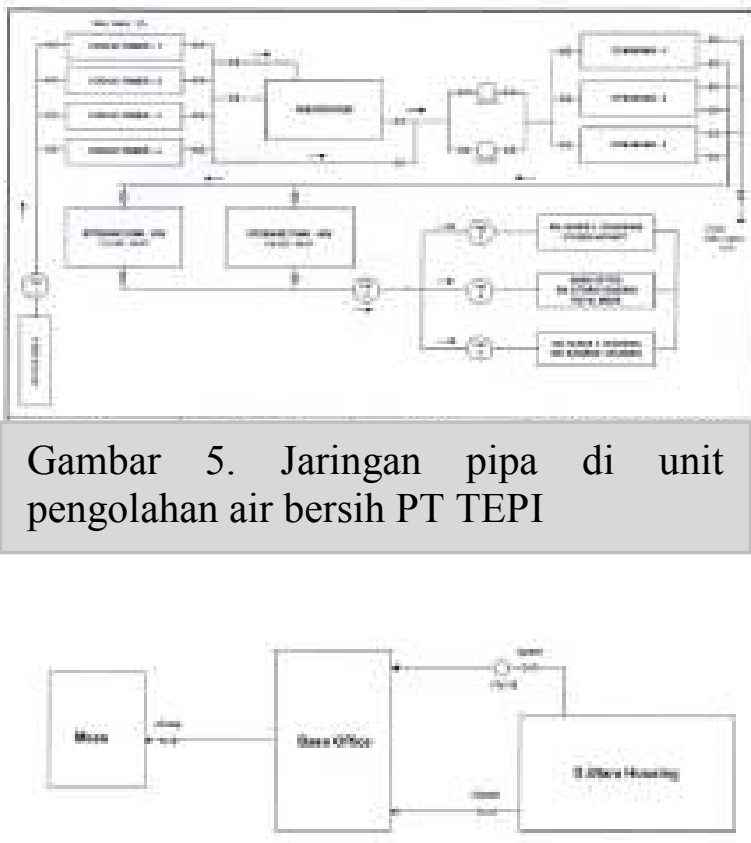

Gambar 6. Jariangan ditribusi pipa air bersih di PT. TEPI

Daftar perbaikan area kebocoran dapat dilihat pada contoh laporan pada tabel 1 dan gambar 7 berikut ini.

Tabel 1. Daftar Perbaikan Area Kebocoran

\begin{tabular}{|c|c|c|c|c|}
\hline $\begin{array}{l}\mathbf{N} \\
\mathbf{0}\end{array}$ & Tgl & $\begin{array}{c}\text { Jenis } \\
\text { Kerus } \\
\text { akan }\end{array}$ & Lokasi & $\begin{array}{l}\text { Tindakan } \\
\text { Perbaikan }\end{array}$ \\
\hline 1 & $\begin{array}{c}\mathrm{Me} \\
\text { i } \\
09\end{array}$ & $\begin{array}{l}\text { Neepl } \\
\text { e pipe } \\
1 " \\
\text { supply }\end{array}$ & $\begin{array}{l}\text { Ged. } \\
\text { OFH }\end{array}$ & $\begin{array}{l}\text { Perbaikan dan } \\
\text { penggantian neeple }\end{array}$ \\
\hline 2 & $\begin{array}{c}9 \\
\text { Jun } \\
09\end{array}$ & $\begin{array}{l}\text { Pipe } \\
2 " \\
\text { supply }\end{array}$ & $\begin{array}{l}\text { Ged. } \\
\text { Klinik }\end{array}$ & $\begin{array}{l}\text { Membuat saluran } \\
\text { baru }\end{array}$ \\
\hline
\end{tabular}



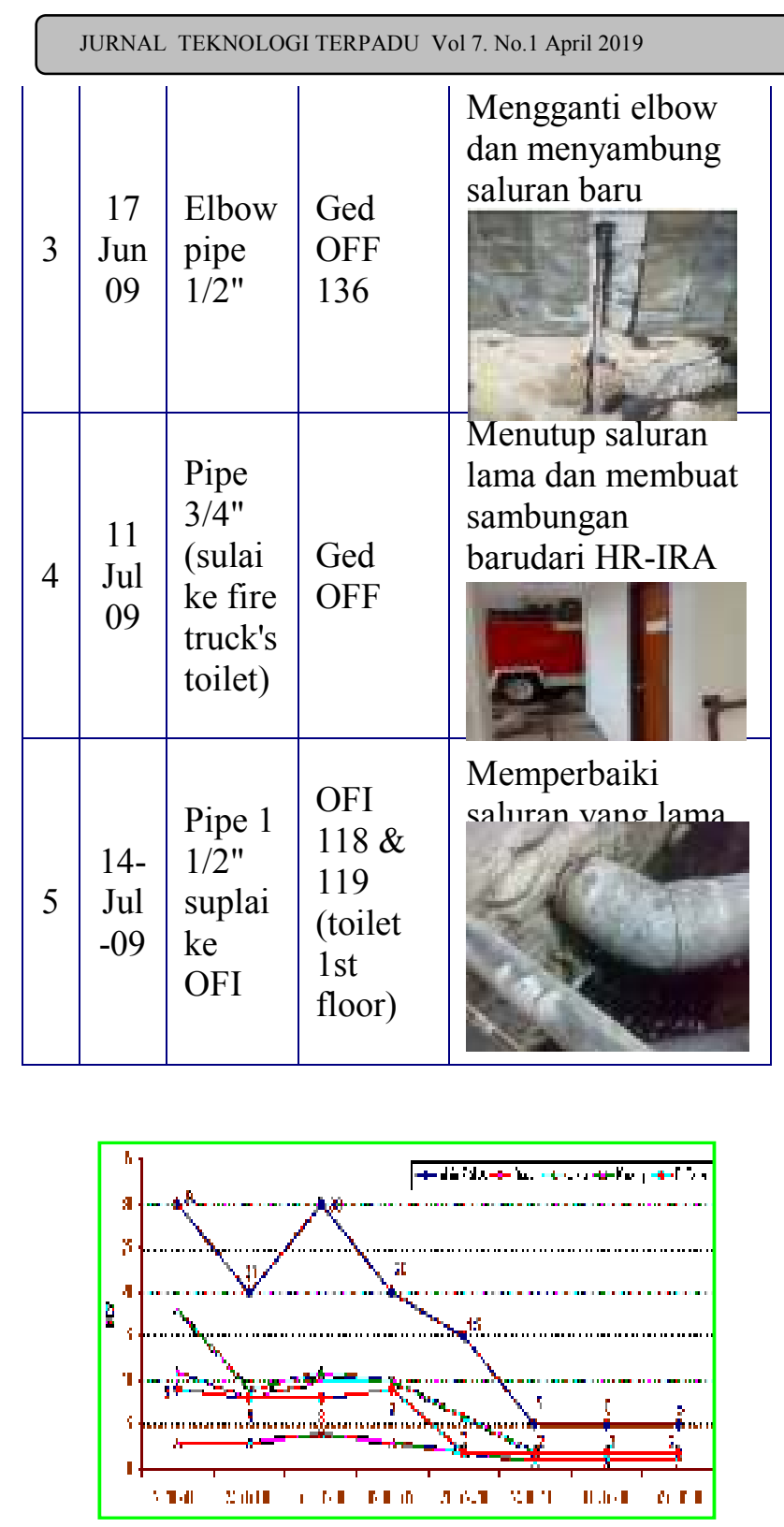

Gambar 7. Data setelah titik kebocoran diperbaiki

\section{f. Pelaksanaan Rekomendasi Hasil Studi} Pendahuluan

Dalam rangka melaksanakan rekomendasi hasil studi pendahuluan, telah dilakukan beberapa perbaikan dan upaya-upaya lainnya untuk penghematan air, antara lain:

(1) Perbaikan dan Pemasangan Meter Air Meter air sangat penting untuk memantau secara terus menerus jumlah pemakaian air. Selain itu juga berfungsi untuk mengontrol dan mengendalikan pemakaian air setiap bulannya. PT. TEPI telah mengganti dan melakukan kalibrasi terhadap beberapa meter air yang tidak berfungsi. Selain itu juga dilakukan

pemasangan meter air di titik yang berpotensi besar dalam pemakaian air seperti untuk pemakaian air di klinik, area perumahan, dan fasilitas kolam renang.

(2) Pemakaian Keran Hemat Air

Pemakaian keran hemat air bertujuan untuk memberikan kinerja tinggi sekaligus mengurangi jumlah air yang dibutuhkan. Ada beberapa tipe utama keran yang telah diterapkan antara lain:

a. Keran tekan (push taps) yang dapat menutup sendiri setelah dinyalakan/ ditekan (push) dalam waktu tertentu sehingga menghilangkan kemungkinan air dibiarkan mengalir. Pemakaian keran ini dapat menghemat air sampai $50 \%$ dibandingkan dengan keran konvensional[5].

b. Keran sensor yang akan terbuka saat tangan mendekati keran dan otomatis akan berhenti mengalir jika tangan menjauh. Pemakaian keran sensor ini dapat menghemat air lebih dari $70 \%$ dibandingkan dengan pemakaian keran manual [6].

(3) Pemakaian Dual Flush Toilet

Toilet duduk yang menggunakan sistem "flush" menjadikan penyiraman otomatis dengan satu kali gerakan menjadi lebih efisien. Terdapat dua pilihan sistem flush yaitu single flush dan dual flush. Tipe single flush merupakan model klasik sedangkan tipe dual flush menggunakan perbandingan 3:6 liter di mana tombol kecil mengeluarkan 3 liter air dan tombol besar mengeluarkan 6 liter air. Untuk lebih menghemat air beberapa produsen toilet membuat sistem perbandingan $3: 4,5$ liter dan 2,3:4,8 liter [7].

Gedung perkantoran di TEPI menggunakan toilet duduk sistem dual flush.

(4) Pemakaian Shower untuk Mandi Menurut United State Environmental Protection Agency's (EPA's) Water Sense Program standar shower yang digunakan harus mempunyai spesifikasi nilai maksimum flow rate sebesar 7,6 liter per menit. Menurut penelitian Aquacraft tahun 2005 rata- 
rata waktu mandi dengan menggunakan shower adalah 7,93 menit, sehingga pemakaian air untuk mandi dengan shower sebesar 60,27 liter [8]. Apabila dibandingkan dengan mandi menggunakan gayung dan bak mandi/ember akan membutuhkan 75 liter sampai 100 liter [9], maka mandi dengan menggunakan shower akan menghemat sampai $39 \%$ air bersih. TEPI telah menggunakan shower sebagai perangkat untuk mandi pegawai di kantor. Selain hemat air dan efisien juga menghemat tempat/space.

(5) Pemakaian Sprinkler

Salah satu cara untuk menghemat air dalam aktivitas siram taman dan cuci kendaraan adalah dengan menggunakan teknik siraman air. Peraturan Menteri Pekerjaan Umum \& Perumahan Rakyat tentang Sumber Daya Air menjelaskan bahwa penerapan teknologi hemat air dalam menggunakan peralatan penyiraman tanaman dapat berupa irigasi curah (sprinkler) [10]. Sistem irigasi curah adalah metode pemberian air yang dilakukan dengan menyemprotkan air ke udara kemudian jatuh ke permukaan tanah seperti air hujan [11]. TEPI telah memasang beberapa springkler dengan tipe impulse dengan cara kerjanya sangat baik, karena dapat disetting sudut putar yang diinginkan dan juga kebutuhan airnya dapat diatur karena terdapat pusat pengaturan air untuk penyiraman taman.

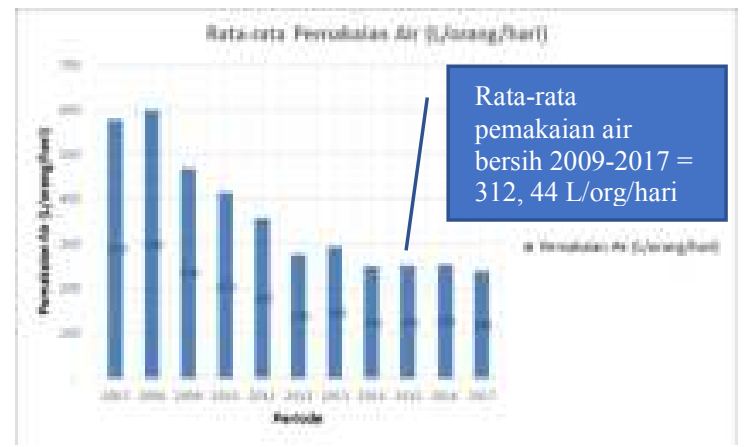

Gambar 8. Pemakaian Air Bersih Rata-rata perkapita (liter/orang.hari) tahun 2009-2017 g. Hasil evaluasi pemakaian air sebelum dan sesudah dilakukan upaya penghematan air adalah:

(1) Sumber air bersih yang digunakan di Kantor TEPI 100\% berasal dari air sumur bawah tanah.

(2) Setelah dilakukan upaya penghematan pemakaian air, maka untuk mengetahui seberapa besar penghematan tersebut akan dibandingkan pemakaian air ratarata bulanan mulai dari tahun 2009-2017 sebesar 21.431,56 $\mathrm{m}^{3}$, dibandingkan dengan pemakaian air di tahun 2008 sebesar $32.563 \mathrm{~m}^{3}$, sebelum program penghematan air ini dilakukan. Gambar 9 memperlihatkan bahwa hasil perbandingan tersebut menunjukkan terjadi penurunan pemakaian air yang cukup signifikan rata-rata sebesar $34,18 \%$.

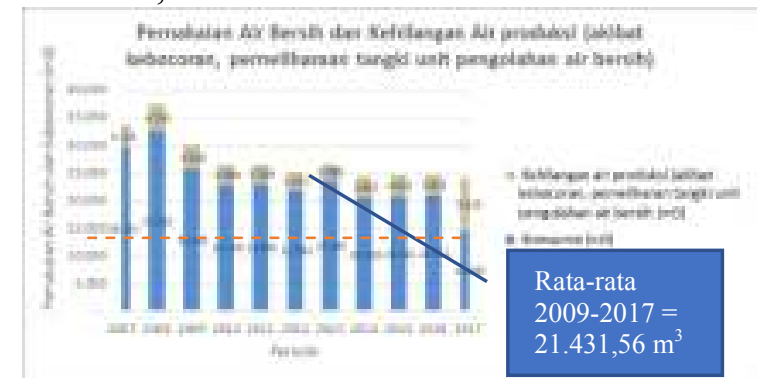

Gambar 9. Pemakaian Air Bersih dari tahun 20092017

\section{KESIMPULAN}

Sebagai hasil dari program penghematan air yang dilakukan, TEPI telah mampu melaksanakan penghematan sebesar $34,18 \%$ dari tahun 2009-2017. Beberapa upaya untuk menghemat air yang telah dilakukan diantaranya komitmen dari manajemen puncak untuk mendukung secara penuh pada gerakan penghematan air, pembentukan komite hemat energi dan air, melakukan sosialisasi peningkatan kesadaran karyawan, deteksi kebocoran air, memperbaiki kran bocor dan meter air yang rusak, mengganti-kran-manual-menjadi kran autostop, pemakaian dual flush toilet, dan sprinkler untuk menyiram tanaman. Sedangkan rata-rata pemakaian air perkapita adalah sebesar 312,44 L/orang/hari. 


\section{SARAN}

Untuk mendapatkan efisiensi penghematan pemakaian air bersih dapat dikembangkan upayaupaya yang berkaitan dengan pembangunan unit daur ulang air limbah, pemanenan air hujan dan pembuatan sumur resapan dapat menjaga kesetimbangan hidrologi air tanah sehingga dapat mencegah intrusi air laut.

\section{UCAPAN TERIMA KASIH}

Ucapan terima kasih kepada Pimpinan dan pihak-pihak terkait yang ada di PT TEPI yang telah memberikan kesempatan untuk melakukan pengamatan, pengambilan data dan evaluasi berdasarkan aturan yang berlaku.

\section{DAFTAR PUSTAKA}

[1] S. Yudo, "Upaya Penghematan Air Bersih di Gedung Perkantoran Water Saving Efforts in Offices Building Case Study: Water Saving in BPPT Office Building," vol. 19, no. 1, pp. 97106, 2018.

[2] Anonym, "Pengelolaan Sumber Daya Air," Peratur. Pemerintah RI, no. 42, 2008.

[3] Anonym, "Penghematan Energi dan Air," no. 13, 2011.

[4] Kementerian Energi dan Sumber Daya Mineral, "Penghematan Penggunaan Air Tanah," no. 15, 2012.
[5] S. Thinking, F. O. R. Better, and B. Series, "Smart Thinking for Better Business Series WATER," ADVICELink, vol. 2, 2014. (http://www.visitscotland.org/pdf/Sustainabilit y\%20Leaflet $\% 20-\% 20$ Water\%20\%20Taps\%20and\%20Showers.pdf).

[6] AutoTap (2015) http://www.autotaps.com/ sensor-taps-facts-and-charts.html, Automatic Taps Facts And Charts. Autotaps (UK) Limited, London.

[7] Kloset Flush yang Makin Efisien. Available from: (http://properti.kompas.com/read/2013/ 09/02/2439/Kloset.Flush.yang.Makin.Efisien)

[8] Sofyan A. (2013). 9. Anonim, (2010). Water Sense Specification for Shower heads Supporting Statement. United State Environmental Protection Agency's (EPA's) WaterSense.

[9] Khamdevi, Moh. (2012). Aplikasi Penggunaan Air Dalam Fiqh Pada Bangunan Hunian: Reduce, Reuse dan Recycle?. Program Studi Arsitektur Universitas Pembangunan Jaya.

[10] Anonim. (2015). Peraturan Menteri PUPR Nomor 9/PRT/M/2015 tentang Penggunaan Sumber Daya Air. 